0278-4343(93)E0001-O

\title{
Exchange of water masses between the East China Sea and the Kuroshio off northeastern Taiwan
}

\author{
C. T. A. Chen, ${ }^{*}$ R. Ruo, ${ }^{*}$ S. C. PAI,$\dagger$ C. T. Liu $\dagger$ and G. T. F. Wong $\ddagger$
}

(Received 5 April 1993; accepted 27 June 1993)

\begin{abstract}
At least six water masses take part in the mixing processes between the East China Sea and the Kuroshio off northeastern Taiwan: the Kuroshio Surface Water (SW), Kuroshio Tropical Water (TW), Kuroshio Intermediate Water (IW), East China Sea Water (ECSW), Coastal Water (CW) and the Taiwan Strait Water (TSW). SW is depleted in nutrients and normalized alkalinity but has the highest temperature and $\mathrm{pH}$ of all these waters. TW has relatively high temperature, and the highest salinity of all waters. The salinity maximum in the Kuroshio is usually between 100 and $300 \mathrm{~m}$ deep, with large interannual and seasonal variability. IW is characterized by a salinity minimum, high nutrient content and alkalinity, but low pH and oxygen. ECSW is low in salinity, temperature and nutrients, but high in oxygen and normalized calcium and alkalinity. CW has low salinity and nutrient content but is high in normalized alkalinity. TSW is generally depleted in nutrients. The characteristics of the above mentioned waters are discussed. The mixing percentages of SW, TW, IW, and the composite Shelf Surface Water (composed of ECSW, CW and TSW) off the northeast corner of Taiwan in September 1988 and December 1989 are calculated.
\end{abstract}

\section{INTRODUCTION}

IT has been known for 50 years, or longer, that blocking of the Kuroshio (Black Stream) by the East China Sea continental shelf break off the northeast corner of Taiwan is responsible for the generation of a shelf-slope circulation pattern that triggers a major exchange between the East China Sea and the western North Pacific Ocean. This temporally and spatially variable exchange engages waters of deep ocean origin and of strong fluvial influence. The interaction of these two water types is similar to that found inshore of the Gulf Stream off the southeast coast of the United States (BLANTON et al., 1981; Arkinson, 1985). The circulation that promotes and sustains this exchange consists of a complicated system of Kuroshio branch currents, meanders, upwelling and frontal eddies (UDA, 1941; LIU et al., 1992).

The Kuroshio water is characterized by high salinity, and is relatively easy to identify in the East China Sea. It is, however, difficult to quantify the mixing percentages of water masses near the East China Sea shelf break. Early attempts to study the mixing processes involving four or more water masses were mostly qualitative (MILLER, 1950; YANG, 1984;

\footnotetext{
${ }^{*}$ Institute of Marine Geology, National Sun Yat-Sen University, Kaohsiung, Taiwan, Republic of China.

$\dagger$ Institute of Oceanography, National Taiwan University, Taipei, Taiwan, Republic of China.

$\ddagger$ Department of Oceanography, Old Dominion University, Norfolk, Virginia, U.S.A.
} 


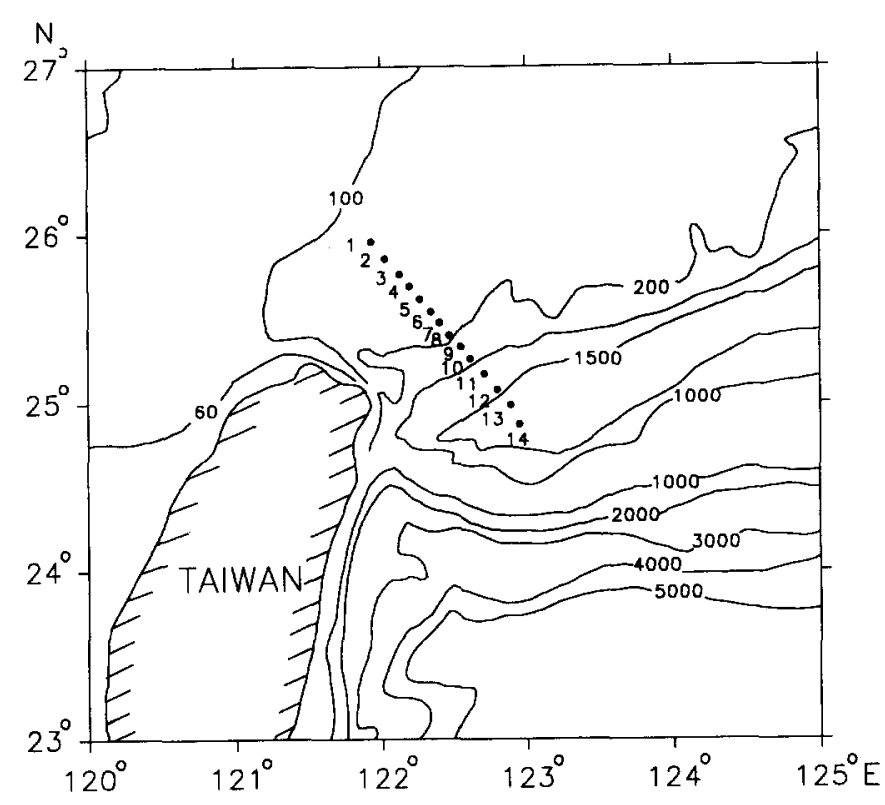

Fig. 1. Station locations. Depth contours are in $\mathrm{m}$.

LI and LU, 1987). We report in this paper two sets of data collected off northeastern Taiwan, one collected in September 1988 and one in December 1989. We also make an attempt to quantify the mixing percentages.

\section{EXPERIMENTAL}

Fourteen stations were occupied by R.V. Ocean Researcher I on 11-14 September 1988 (cruise 179) along a transect normal to the 200-m isobath at the shelf break of the East China Sea (Fig. 1). Eight of these stations were reoccupied during 16-18 December 1989 (cruise 237). Stations 1-7 were located on the shelf in the East China Sea with depths of approximately $100 \mathrm{~m}$. Stations 8-11 were on the continental slope. Stations 12-14 were located in the Okinawa Trough. The water depth at the deepest stations exceeded $1400 \mathrm{~m}$ (RUo, 1989; ChEn et al., 1991).

The profiles of temperature, salinity and total fluorescence were measured by a Seabird SBE 9/11 CTD. The CTD was pumped and the sampling rate was $24 \mathrm{~Hz}$. The sensors were calibrated just before the 179 cruise by the Northwest Regional Calibration Center. Discrete samples were obtained for the determination of dissolved oxygen, phosphate, nitrate, silicate and $\mathrm{pH}$ onboard ship. Oxygen was measured by the Winkler titrimetric method (CARPENTER, 1965) with a precision of about $\pm 0.5 \%$. Phosphate was determined by the molybdenum blue method (MURPHY and RILEY, 1962). Silicate was measured by the silicomolybdenum blue method (FANNING and PILSON, 1973). Nitrate was determined by reducing nitrate to nitrite and then determining the nitrite formed by the azo dye method (STRICKLAND and PARSONS, 1972) with a flow injection analyzer. $\mathrm{pH}$ was measured on the NBS scale with a glass electrode/calomel electrode pair at $25^{\circ} \mathrm{C}$ (CHEN, 1984; Ruo, 1989; 
Wong et al., 1989a,b). Alkalinity was measured by Gran Titration (BRADshow et al., 1981).

\section{Water masses in the study area}

At least six water masses take part in the mixing processes (CHEN, 1988a); the Kuroshio Surface Water (SW), Kuroshio Tropical Water (TW), Kuroshio Intermediate Water (IW), East China Sea Water (ECSW), Coastal Water (CW), and the Taiwan Strait Water (TSW). SW is depleted in nutrient and normalized alkalinity (NTA $=$ alkalinity $\times 35 / S$ ) but has the highest temperature and $\mathrm{pH}$ of all these waters (Fig. 2). The salinity is also high, albeit somewhat lower than TW mainly because of precipitation and mixing with fresher shelf and coastal waters (Fig. 3). A prism of fresher surface water extending offshelf is underlain by the shelfward intrusion of deeper and more saline offshore waters (Fig. 3). The layer immediately beneath SW is TW which has relatively high temperature, and the highest salinity of all waters. The salinity maximum in the Kuroshio is usually between 100 and $300 \mathrm{~m}$ deep, shallower in winter and deeper in summer with a large interannual variability. TW is clearly recognizable as a salinity maximum near the shelf break. The temperature, salinity and density stratifications are stronger in summer than in winter (CHEN, 1988a; Figs 2-4).

Topographically induced upwelling at the shelf break is evident as indicated by the shelfward- and upward-tilting isotherms, isohalines, and isopycnals which extend over the shelf break (Figs 2-4). At the shelfward edge of the upwelling water, the isotherms, isohalines and isopycnals formed a bulge. The frequently detected bulge has a dimension of a few tens of kilometers. It may be caused by strong upwelling or else may represent eddies, filaments, or meandering of the Kuroshio (Wong et al., 1991).

The above mentioned bulge of subsurface upwelling water is also evident in the apparent oxygen utilization (AOU, calculated based on the equation of CHEN, 1981), nitrate, phosphate, silicate and $\mathrm{pH}$ cross-sections (Figs 5-9). In the surface waters, the AOU is near zero, the nutrients are all low but the $\mathrm{pH}$ is high. The upwelling water has high AOU and nutrients but has low $\mathrm{pH}$. Subsurface waters on the shelf show much variability, but in general, the vertical gradients are larger on the shelf than offshore.

IW is located between 400 and $600 \mathrm{~m}$ beneath TW, and is characterized by a salinity minimum (Fig. 3), high nutrient content and alkalinity, but low pH and oxygen (Figs 5-9). The minimum salinity core does not upwell onto the shelf (Fig. 3). Only isopleths saltier than 34.45 , warmer than $14^{\circ} \mathrm{C}$, contain more than $3.4 \mathrm{ml} \mathrm{l}^{-1} \mathrm{O}_{2}$, and shallower than $450 \mathrm{~m}$ in the Kuroshio (saltier than 34.50 , warmer than $15^{\circ} \mathrm{C}$, contain more than $3.6 \mathrm{ml} \mathrm{I}^{-1} \mathrm{O}_{2}$, and shallower than $350 \mathrm{~m}$ in summer) seem to extend onto the shelf (CHEN, 1988a). Four of the above mentioned major water types can be seen on the $T-S$ diagrams for the December cruise (Fig. 10).

ECSW is low in salinity, temperature and nutrients, but high in oxygen and NTA. Coastal water has a wide temperature and salinity range. Since we are not studying the mixing of river waters and seawater, we choose a salinity of 28 to represent $\mathrm{CW}$. CW has low salinity and nutrient contents but is high in NTA.

Taiwan Strait Water moves mainly northward year round, except that some surface water may move southward in winter (we exclude from this study the coastal water flowing southward along the Fukien coast). TSW is generally depleted in nutrients. The characteristics of the above mentioned waters are listed in Table 1 (WANG, 1988; ChEN, 1988a). 
(a) station

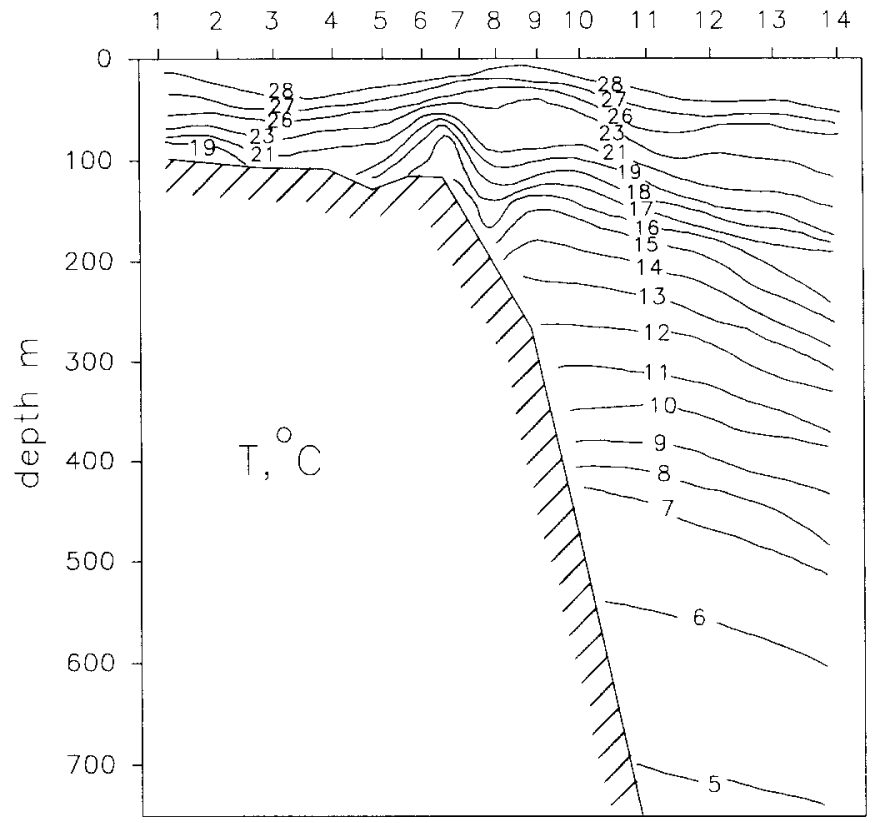

(b)

station

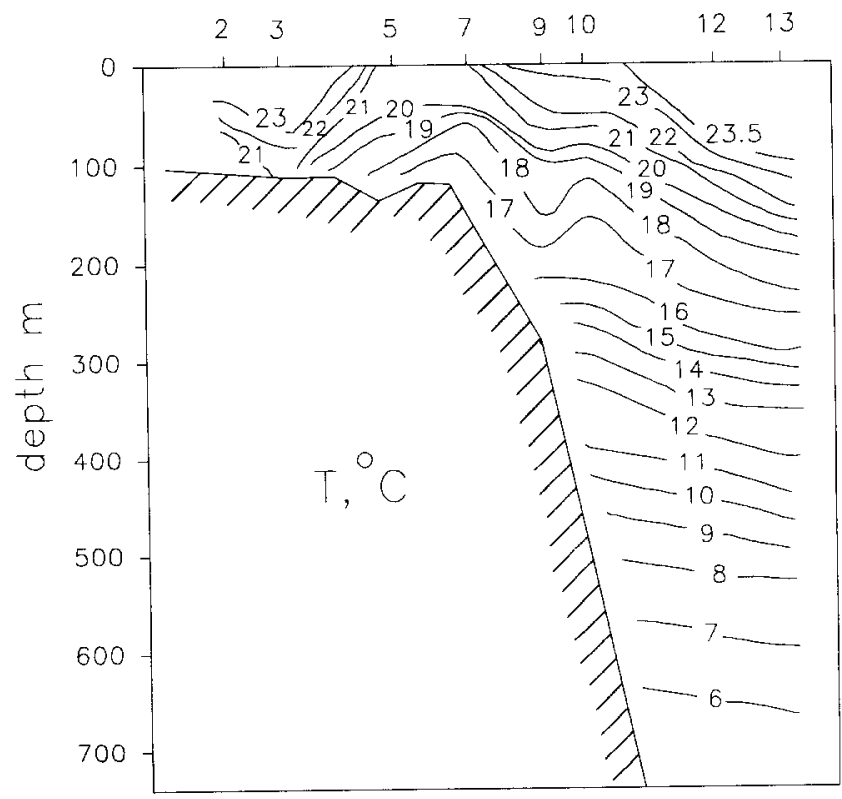

Fig. 2. Cross-section of temperature in (a) September 1988 and (b) December 1989. 
(a)

station

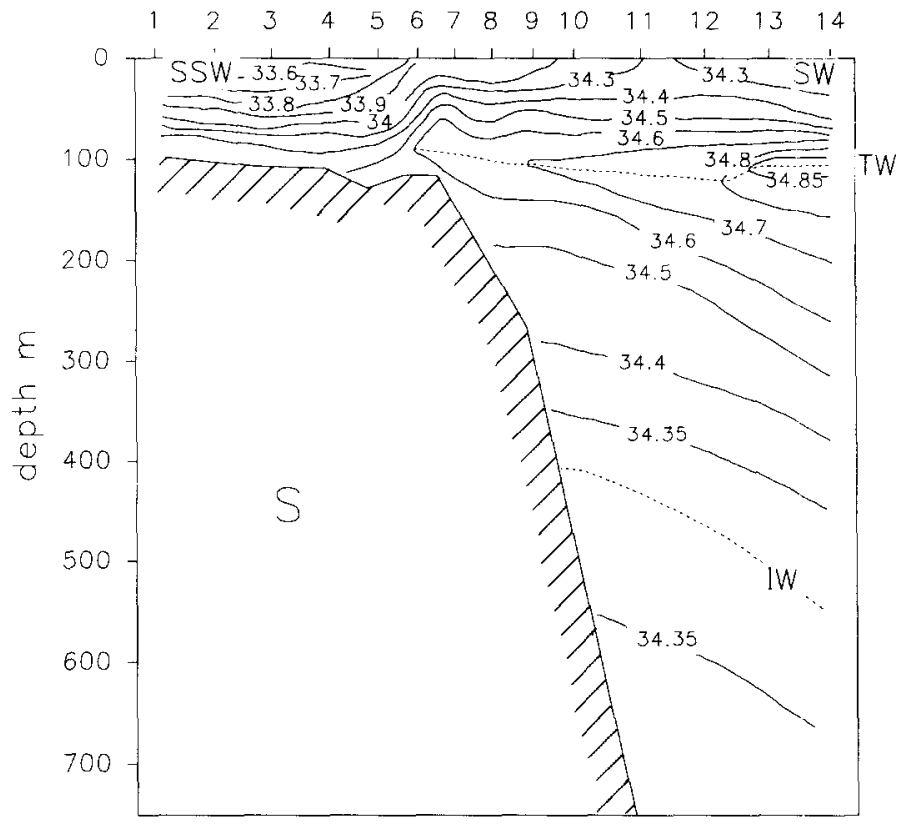

(b)

station

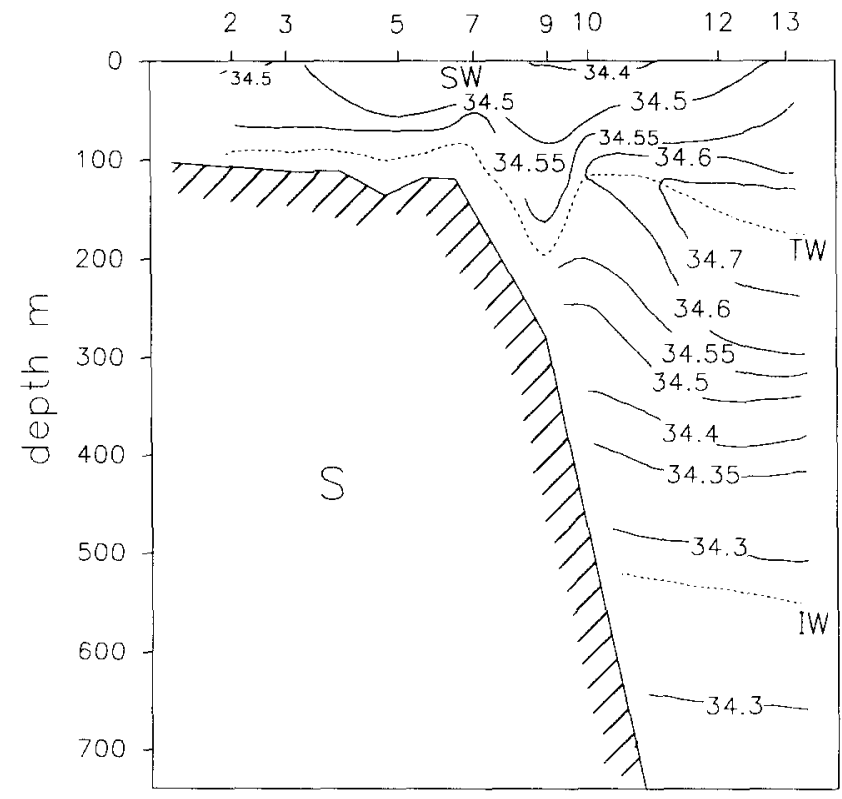

Fig. 3. Cross-section of salinity in (a) September 1988 and in (b) December 1989. The broken lines show the salinity extremes. The major water types SSW, SW, TW and IW are marked. 
(a)

station

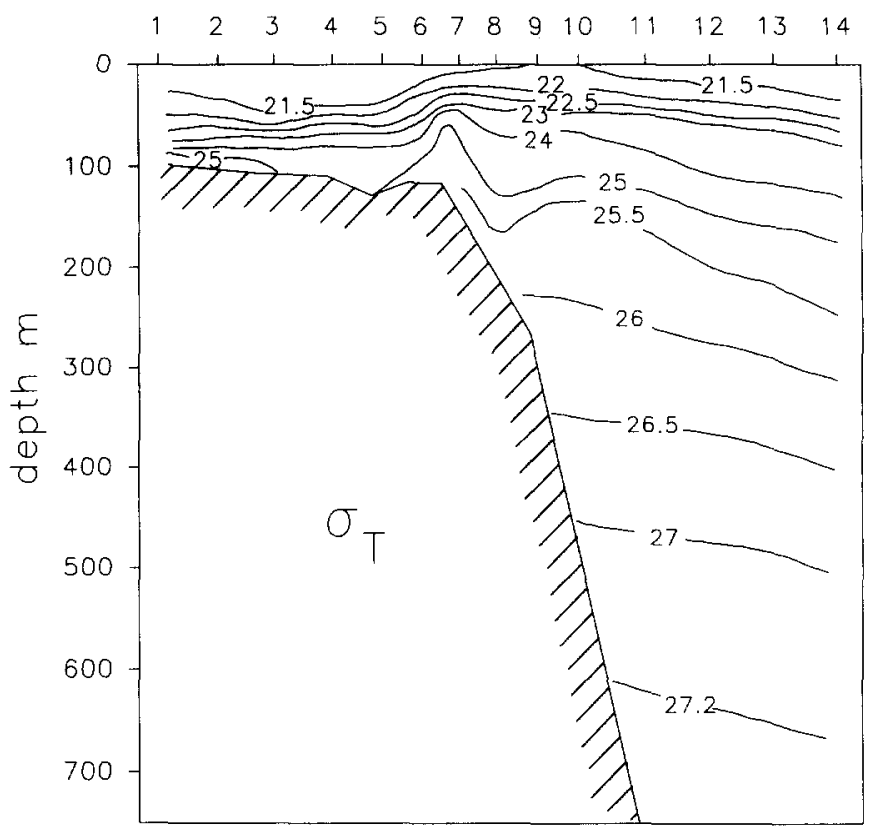

(b)

station

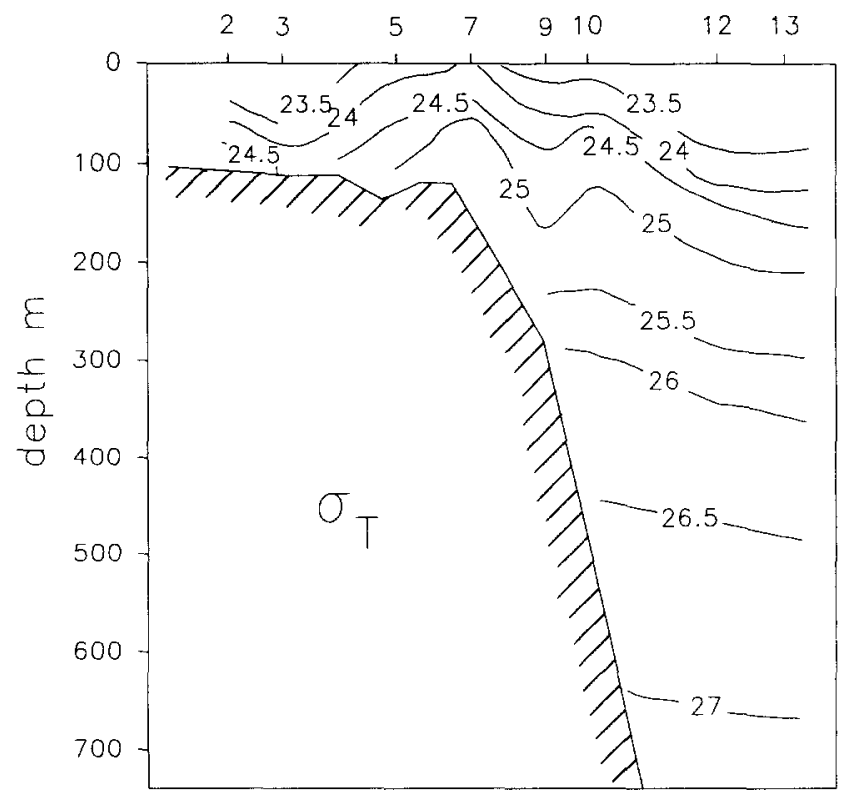

Fig. 4. Cross-section of $\sigma_{t}$ in (a) September 1988 and in (b) December 1989. 
(a)

station

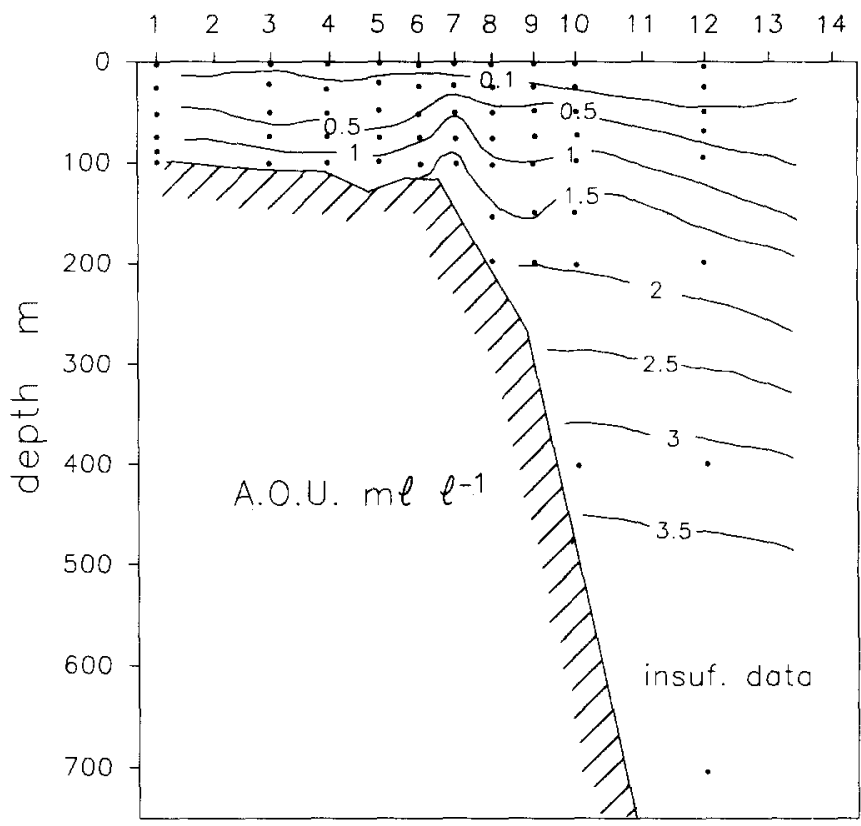

(b)

station

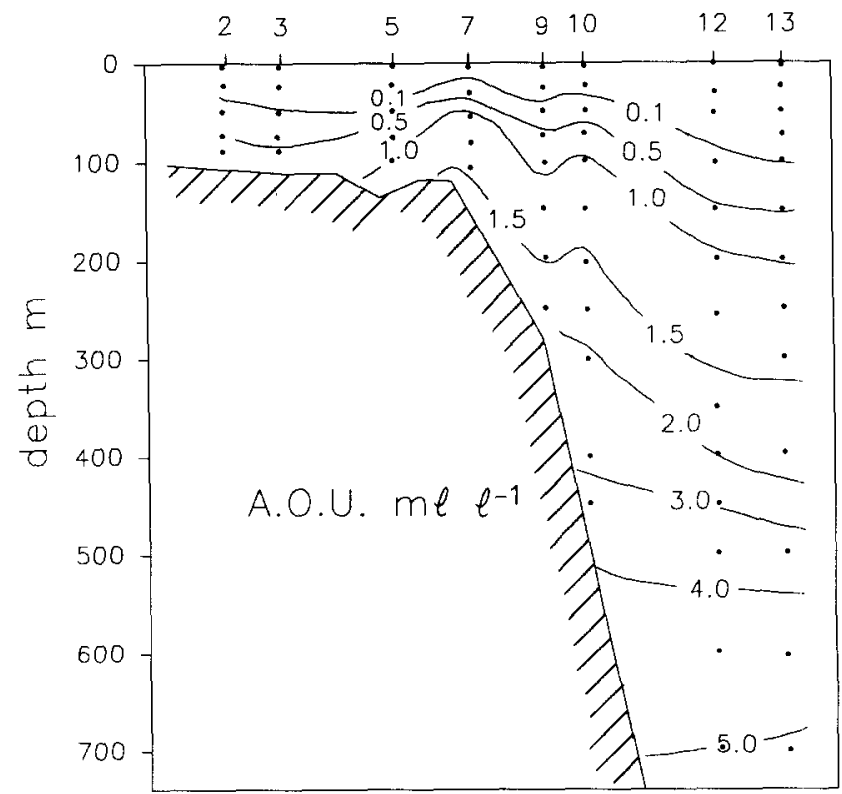

Fig. 5. Cross-section of apparent oxygen utilization in (a) September 1988 and in (b) December 1989. 
(a)

station

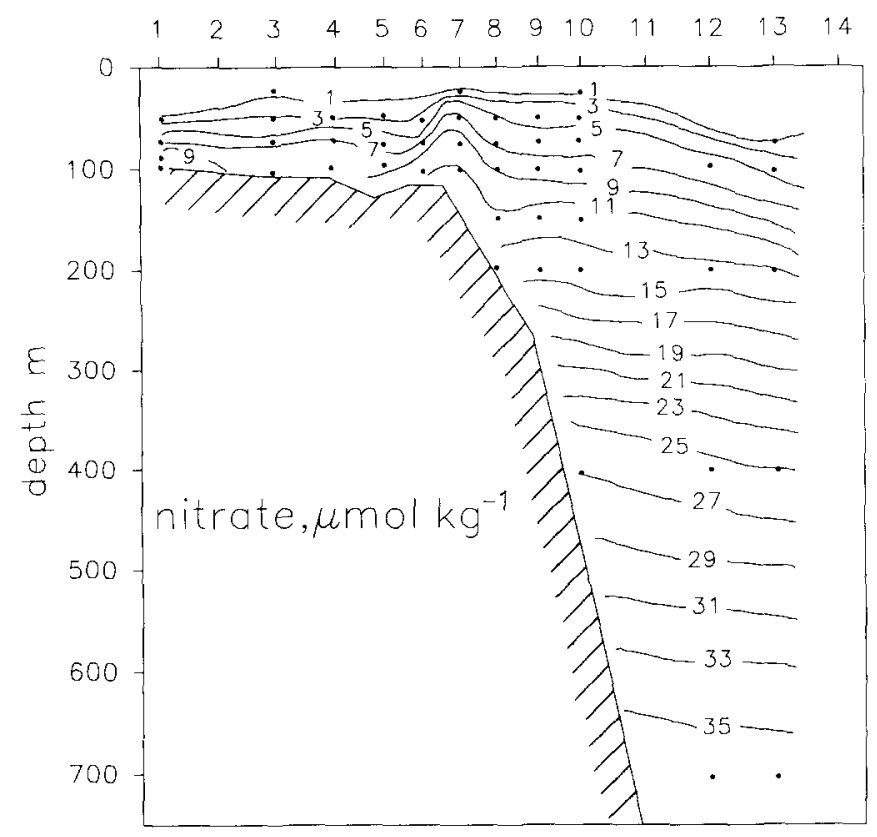

(b)

station

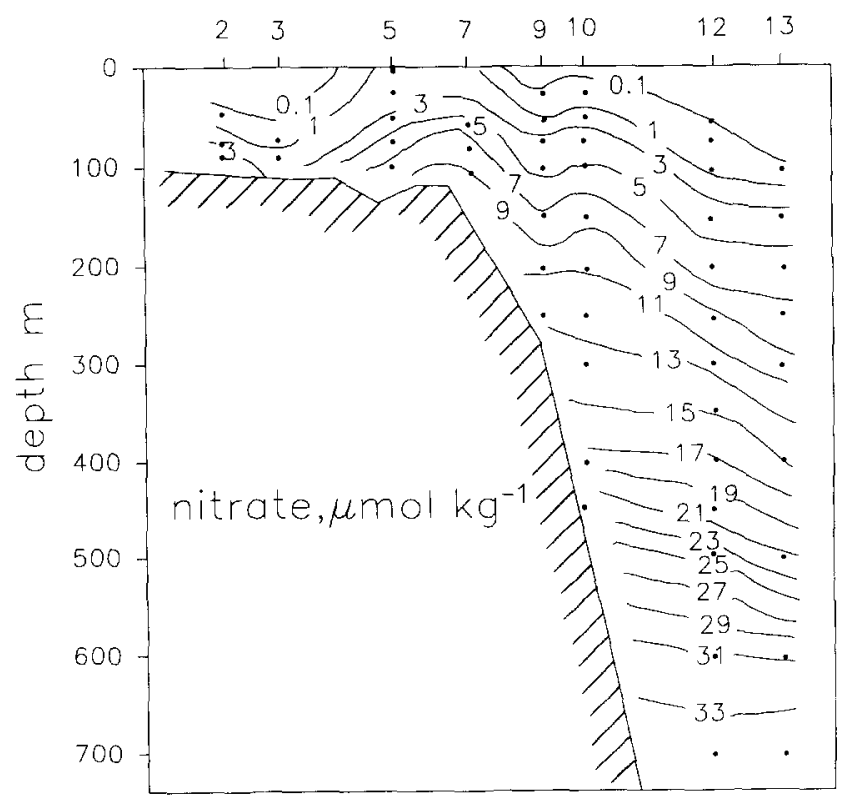

Fig. 6. Cross-section of nitrate in (a) September 1988 and in (b) December 1989. 
(a)

station

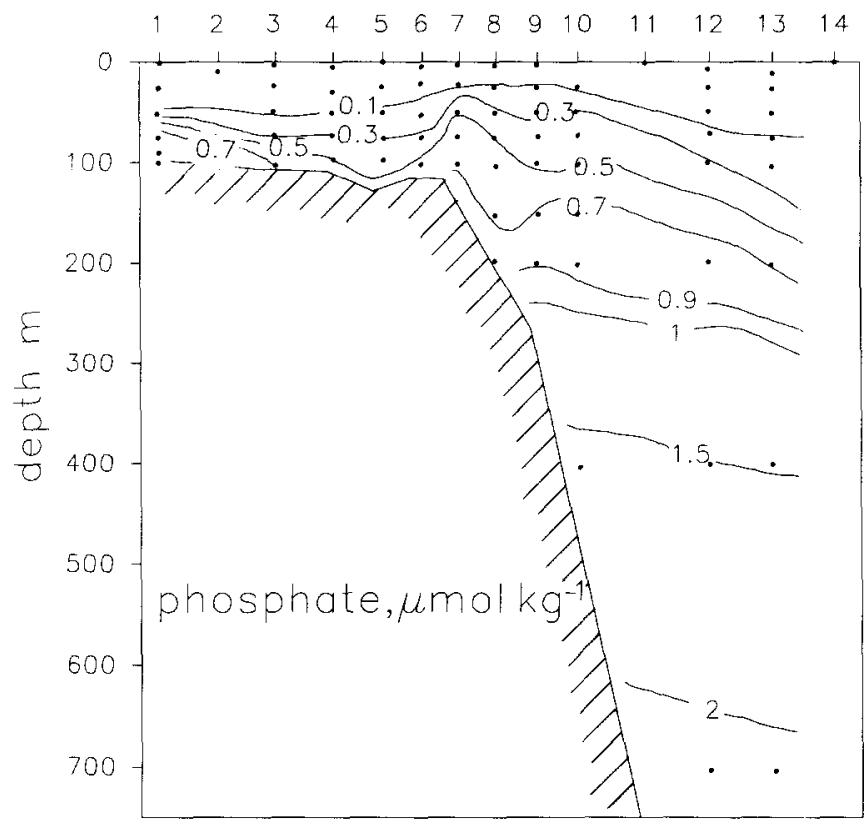

(b)

\section{station}

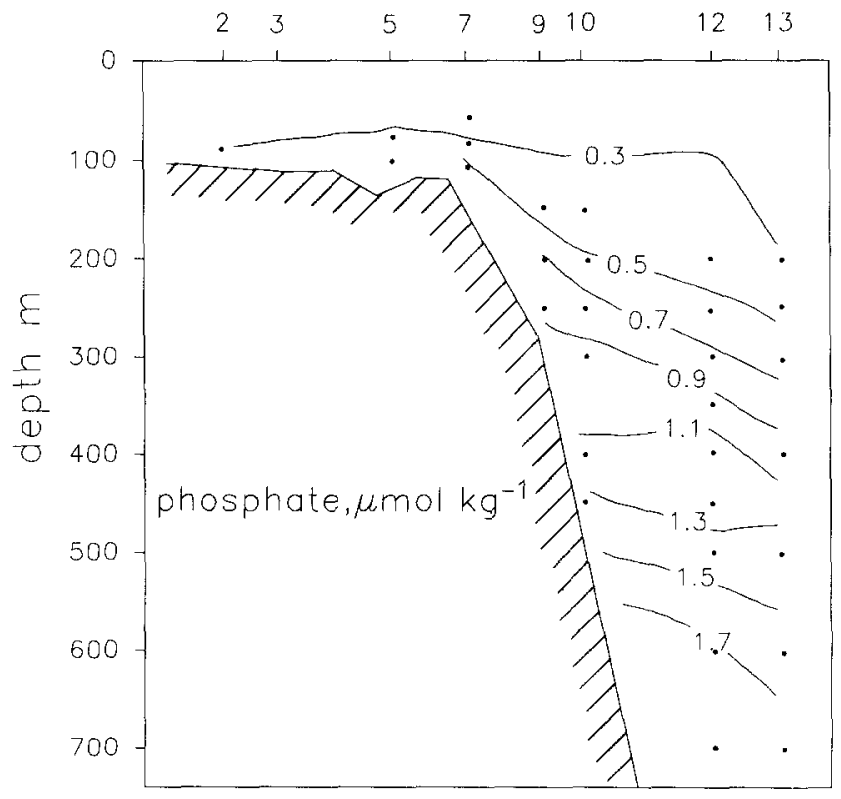

Fig. 7. Cross-section of phosphate in (a) September 1988 and in (b) December 1989. 
(a)

station

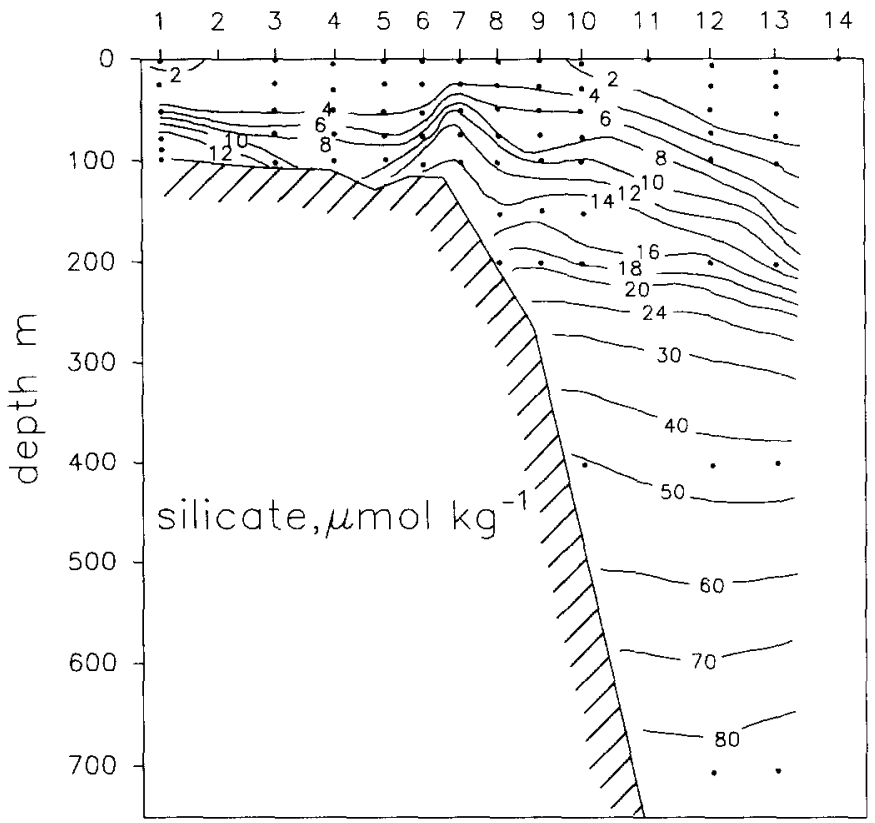

(b)

station

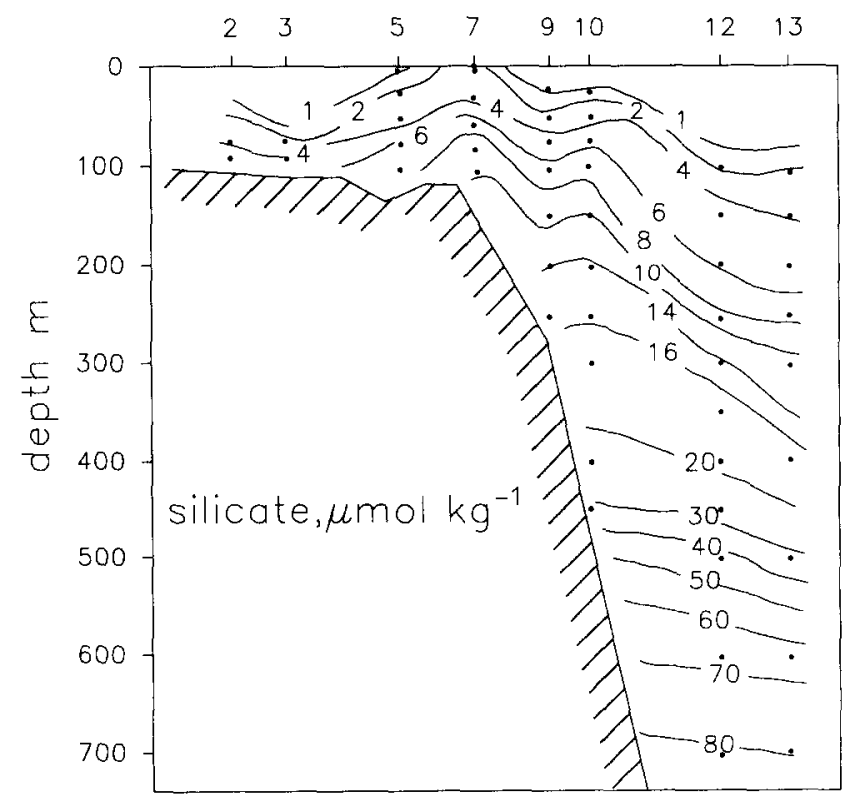

Fig. 8. Cross-section of silicate in (a) September 1988 and in (b) December 1989. 
(a) station

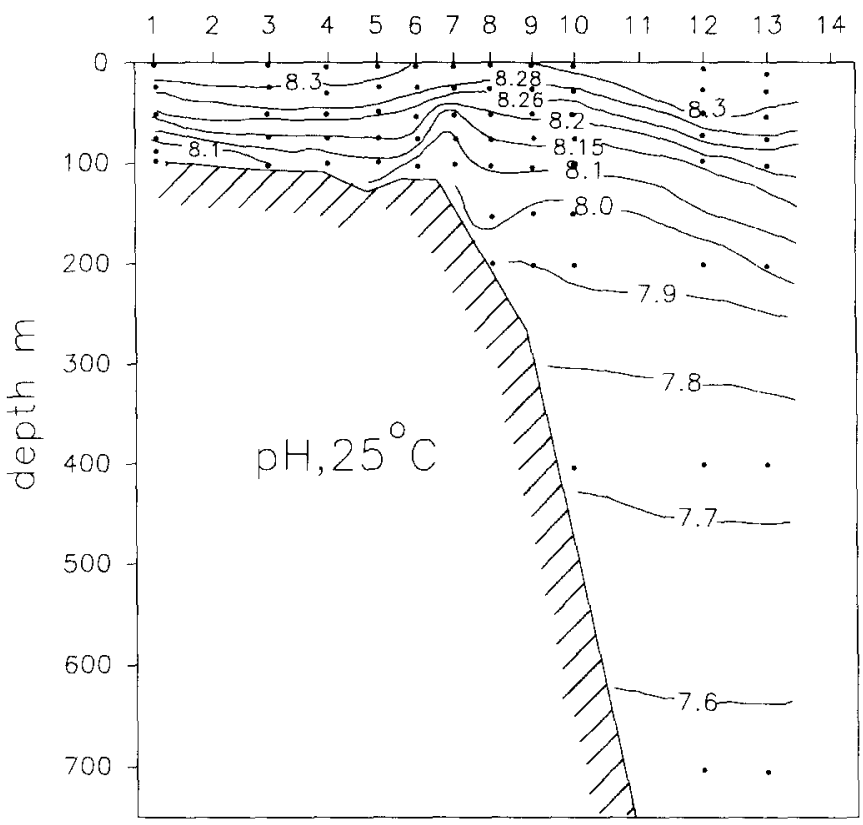

(b) station

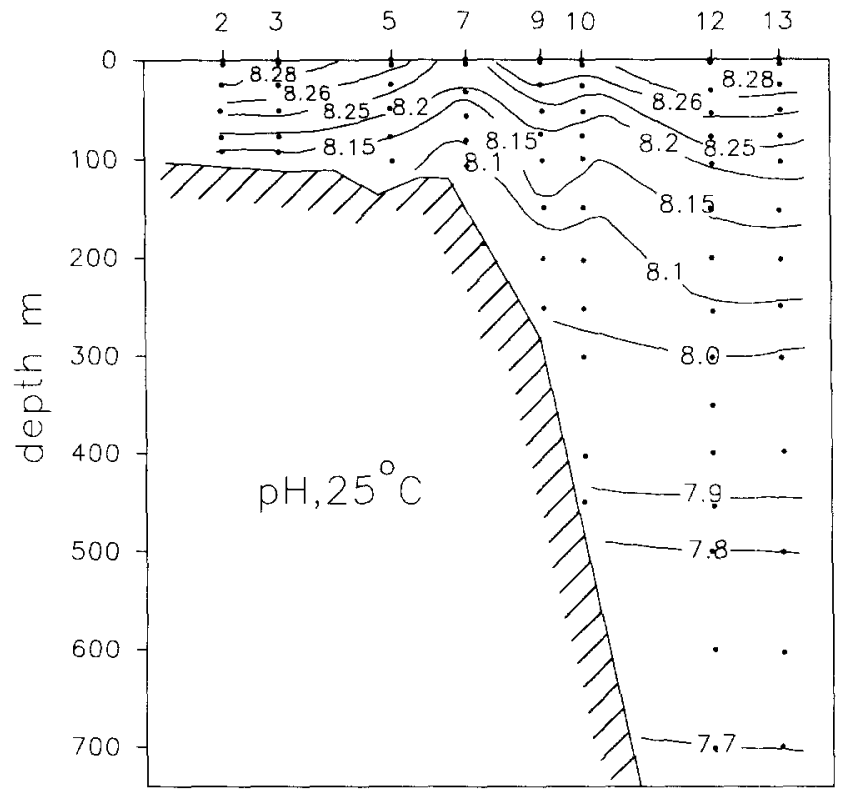

Fig. 9. Cross-section of pH in (a) September 1988 and in (b) December 1989. 


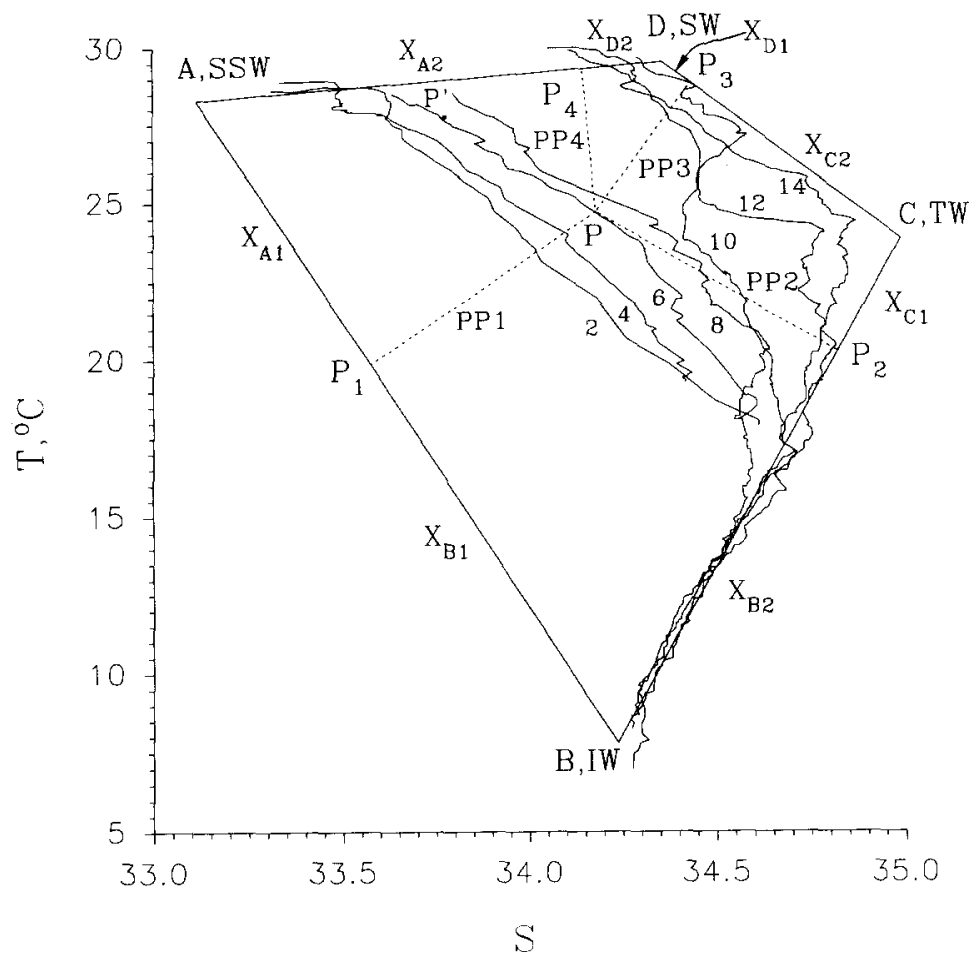

Fig. 10. Diagram representing mixing of four water masses. The CTD data for Stas 2, 4, 6, 8, 10 12 and 14 of the September cruise are also plotted.

Table 1. Typical salinity, temperature, oxygen, $p H$, normalized alkalinity, nitrate, phosphate and silicate for $S W$, $T W, I W, E C S W, C W$ and $T S W$

\begin{tabular}{|c|c|c|c|c|c|c|c|c|}
\hline & $S$ & $T,{ }^{\circ} \mathrm{C}$ & $\begin{array}{c}\mathrm{O}_{2} \\
\left(\mathrm{ml} \mathrm{l}^{-1}\right)\end{array}$ & $\mathrm{pH}$ & $\begin{array}{c}\text { NTA } \\
\left(\mathrm{mmol} \mathrm{kg}^{-1}\right)\end{array}$ & $\begin{array}{c}\mathrm{NO}_{3} \\
\left(\mu \mathrm{mol} \mathrm{kg}^{-1}\right)\end{array}$ & $\begin{array}{c}\mathrm{PO}_{4} \\
\left.(\mu \mathrm{mol} \mathrm{kg})^{-1}\right)\end{array}$ & $\begin{array}{c}\mathrm{SiO}_{2} \\
(\mu \mathrm{mol} \mathrm{kg}-1)\end{array}$ \\
\hline SW & $34.30-34.70$ & $24.5-29.0$ & $4.20-4.80$ & $8.00-8.30$ & $2.30-2.32$ & $0.2-2.7$ & $0-1.2$ & $2-8$ \\
\hline TW & $34.85-34.90$ & $20.0-23.4$ & $4.00-4.34$ & $8.10-8.20$ & $2.30-2.32$ & $0.6-2.5$ & $0.5-1.1$ & $2-14$ \\
\hline IW & $34.25-34.30$ & $6.6-8.0$ & $2.10-2.80$ & $7.50-7.80$ & $2.36-2.41$ & $20-30$ & $1.6-2.3$ & $40-80$ \\
\hline ECSW & $30.50-33.50$ & $8.6-20.0$ & $3.00-4.80$ & $8.10-8.30$ & $2.37-2.57$ & $0-10$ & $0-0.6$ & $15-40$ \\
\hline $\mathrm{CW}$ & 28 & $13.0-25.0$ & $5.20-6.80$ & $8.10-8.50$ & $2.37-2.57$ & $0-20$ & $0-0.5$ & $15-40$ \\
\hline TSW & $33.70-34.60$ & $19.0-28.0$ & $4.00-5.20$ & $8.00-8.30$ & $2.28-2.32$ & $0-2$ & $0-1.5$ & $0-15$ \\
\hline
\end{tabular}

The traditional $T-S$ method is useful for describing surface and shelf waters (Mao et al., 1964; CHEN, 1985; CHEN et al., 1985), but the uncertainty is large because neither $T$ nor $S$ is strictly conservative. Oxygen, \% oxygen saturation or AOU are subject to the same limitations because of air-sea exchange, biological activities and temperature variations (which affect percentage oxygen saturation and AOU). These properties are less useful in summer but are more useful in winter when mixing becomes relatively more important relative to biological activities. Nutrients, total carbon dioxide $\left(\mathrm{TCO}_{2}\right)$ or $\mathrm{pH}$ are subject to similar problems as oxygen (CHEN, 1985, 1988b, 1993; CHEN et al., 1985). 
Calcium and alkalinity are more conservative on a shelf, especially when normalized to the same salinity (CHEN, 1985; WANG, 1988). Chinese coastal waters also have higher normalized calcium (NCa) and normalized alkalinity (NTA) than Kuroshio waters because river waters generally have high NCa and NTA values (CHEN et al., 1985; SUI, 1986).

Typical salinity, temperature, oxygen, $\mathrm{pH}$, normalized alkalinity, nitrate, phosphate and silicate for SW, TW, IW, ECSW, CW and TSW are given in Table 1 based on data from the following reports: UDA, 1941; CHU, 1963; CSK, 1966, 1968, 1969, 1970; NITANI, 1972; HuAng et al., 1983; Limeburner et al., 1983; Weng and WANG, 1985; Sui, 1986; WANG, 1988; Ruo, 1989; and Wong et al., 1989a,b, 1991.

\section{Method for calculating the mixing percentages for a four component mixing}

We have made an initial attempt to quantify the mixing percentages of four major water masses based on data collected on R.V. Ocean Researcher I (Ruo, 1989; WoNG et al., 1989a,b, 1991; CHEN et al., 1991). Because there are insufficient data, ECSW, CW and TSW have been grouped together as the Shelf Surface Water (SSW; $S=33.1, T=28^{\circ} \mathrm{C}$, $\mathrm{NO}_{3}=0.2 \mu \mathrm{mol} \mathrm{kg}{ }^{-1}, \mathrm{PO}_{4}=0 \mu \mathrm{mol} \mathrm{kg}^{-1}$ and $\mathrm{pH}=8.3$ in September 1988; $S=33.8, T=$ $19^{\circ} \mathrm{C}, \mathrm{NO}_{3}=2 \mu \mathrm{mol} \mathrm{kg}{ }^{-1}, \mathrm{PO}_{4}=0 \mu \mathrm{mol} \mathrm{kg}^{-1}$ and $\mathrm{pH}=8.2 \mathrm{in}$ December 1989). The four major water types, SSW, SW, TW and IW are marked on Fig. 3(a). SSW is mostly not present near the study area in winter thus only SW, TW and IW are marked on Fig. 3(b).

Assuming that a water mass $\mathrm{P}$ is a mixture of four water masses $\mathrm{A}, \mathrm{B}, \mathrm{C}$, and D (Fig. 10). By drawing perpendicular lines from $P$ to the four sides of the tetragonal we obtain four intercepts, $P_{1}, P_{2}, P_{3}$ and $P_{4}$. The length between $P$ and $P_{1}$ is represented as $P P_{1}$. Likewise the lengths between: $P$ and $P_{2}=P P_{2} ; P$ and $P_{3}=P P_{3} ; P$ and $P_{4}=P P_{4} ; P_{1}$ and $A=X_{A 1} ; P_{1}$ and $B=X_{B 1} ; P_{2}$ and $B=X_{B 2} ; P_{2}$ and $C=X_{C 1} ; P_{3}$ and $C=X_{C 2} ; P_{3}$ and $D=X_{D 1} ; P_{4}$ and $D=X_{D 2} ; P_{4}$ and $A=X_{A 2}$.

Let $f_{A}, f_{B}, f_{C}$ and $f_{D}$ be the fractions of $\mathrm{A}, \mathrm{B}, \mathrm{C}, \mathrm{D}$ in $\mathrm{P}$ :

$$
f_{A}+f_{B}+f_{C}+f_{D}=1
$$

Likewise we can let $f_{P 1}, f_{P 2}, f_{P 3}$ and $f_{P 4}$ be the fractions of $P_{1}, P_{2}, P_{3}$ and $P_{4}$ in P:

$$
f_{P 1}+f_{P 2}+f_{P 3}+f_{P 4}=1 \text {. }
$$

In other words, $T$ and $S$ of $P$ can now be calculated from the $T$ and $S$ of $P_{1}, P_{2}, P_{3}$ and $P_{4}$. The $T$ and $S$ of $P_{1}$ can be calculated from $f_{A 1}, f_{B 1}, X_{A 1}$ and $X_{B 1}$ where $f_{A 1}$ and $f_{B 1}$ are the fractions of $A$ and $B$, respectively, involved in forming $P_{1}$. The objective now is to solve for $f_{A 1}, f_{A 2}, f_{B 1}, f_{B 2}, f_{C 1} f_{C 2}, f_{D 1}, f_{D 2}$.

Water mass $A$ also contributes $f_{A 2}$ to mix with water mass $D$ to form water mass $P_{4}$. Thus $A$ contributes $f_{A 1}$ and $f_{A 2}$ altogether to form $P$. Similarly the contributions of B, C and D can also be subdivided into two parts. Equation (1) now becomes:

$$
f_{A 1}+f_{A 2}+f_{B 1}+f_{B 2}+f_{C 1}+f_{C 2}+f_{D 1}+f_{D 2}=1 .
$$

Further, $P P_{1}$ is inversely proportional to $f_{A 1}+f_{B 1}$ giving the following equation:

$$
P P_{1} \cdot\left(f_{A 1}+f_{B 1}\right)=P P_{2} \cdot\left(f_{B 2}+f_{C 1}\right)=P P_{3} \cdot\left(f_{C 2}+f_{D 1}\right)=P P_{4} \cdot\left(f_{D 2}+f_{A 2}\right) \text {. }
$$

On the four sides of the tetragonal: 
$f_{A 1} \cdot X_{A 1}=f_{B 1} \cdot X_{B 1}, f_{B 2} \cdot X_{B 2}=f_{C 1} \cdot X_{C 1}, f_{C 2} \cdot X_{C 2}=f_{D 1} \cdot X_{D 1}, f_{D 2} \cdot X_{D 2}=f_{A 2} \cdot X_{A 2}$

By solving equations (2)-(4), we obtain:

$$
\begin{array}{cl}
f_{A 1}=\frac{X_{B 1}}{A B \cdot P P_{1}}\left(\sum_{4} \frac{1}{P P_{i}}\right)^{-1} & f_{A 2}=\frac{X_{D 2}}{D A \cdot P P_{4}}\left(\sum_{4} \frac{1}{P P_{i}}\right)^{-1} \\
f_{B 1}=\frac{X_{A 1}}{A B \cdot P P_{1}}\left(\sum_{4} \frac{1}{P P_{i}}\right)^{-1} & f_{B 2}=\frac{X_{C 1}}{B C \cdot P P_{2}}\left(\sum_{4} \frac{1}{P P_{i}}\right)^{-1} \\
f_{C 1}=\frac{X_{B 2}}{B C \cdot P P_{2}}\left(\sum_{4} \frac{1}{P P_{i}}\right)^{-1} & f_{C 2}=\frac{X_{D 1}}{C D \cdot P P_{3}}\left(\sum_{4} \frac{1}{P P_{i}}\right)^{-1} \\
f_{D 1}=\frac{X_{C 2}}{C D \cdot P P_{3}}\left(\sum_{4} \frac{1}{P P_{i}}\right)^{-1} & f_{D 2}=\frac{X_{A 2}}{D A \cdot P P_{4}}\left(\sum_{4} \frac{1}{P P_{i}}\right)^{-1},
\end{array}
$$

where

$$
\sum_{4} \frac{1}{P P_{i}}=\frac{1}{P P_{1}}+\frac{1}{P P_{2}}+\frac{1}{P P_{3}}+\frac{1}{P P_{4}}
$$

It is now possible to calculate the mixing percentages in the study area (MAo, 1964; Ruo, 1989; CHEN et al., 1990). Strictly speaking, however, $T$ and $S$ are not conservative properties near surface, but neither are any of the parameters that we measured. We tried to make the calculation using $T-S, \mathrm{NO}_{3}-S, \mathrm{PO}_{4}-S$ and $\mathrm{pH}-S$ pairs and found little difference (Table 2). We thus decided to use $T-S$ as these data are the most reliable.

\section{RESULTS AND DISCUSSION}

Figure 11(a) and (b) show the percentages of shelf water in September 1988 and December 1989, respectively. In September, the shelf water dominates on the shelf, but only in the surface layer. The percentage reduces to below $50 \%$ below $60 \mathrm{~m}$. The shelf water spreads out off the shelf break and the shelf water percentage reduces rapidly to $1 \%$ before reaching Sta. 14. In December the picture is quite different [Fig. 11(b)]. The shelf water makes up only $20 \%$ of the surface water on the shelf, reflecting reduced river flow from the continent and stronger Kuroshio intrusion in winter.

Figure 12(a) and (b) show the percentages of Kuroshio Surface Water, which dominates off the shelf break. The percentage is higher than $90 \%$ in September in the Kuroshio region, slightly lower in December. The dome-like structure at the shelf break reflects upwelling of deeper waters. The Kuroshio Surface Water contributes approximately $30 \%$ of the water on the shelf in September, and up to $70 \%$ in December when the continental fresh water outflow is low.

Figure 13(a) and (b) show the mixing ratio of the Kuroshio Tropical Water in September and December, respectively. The core of the Tropical Water is near the salinity maximum at about $150 \mathrm{~m}$ in September, slightly deeper in December. The Tropical Water does not 
Table 2. Mixing ratios based on $\mathrm{T}-\mathrm{S}, \mathrm{NO}_{3}-\mathrm{S}, \mathrm{PO}_{4}-\mathrm{S}$ and $\mathrm{pH}-\mathrm{S}$ pairs for cruise 179

\begin{tabular}{|c|c|c|c|c|c|c|c|c|c|c|c|c|c|c|c|}
\hline Method & & $T-S$ & & & & $\mathrm{NO}_{3}^{-}$ & & & & $\mathrm{PO}_{4}^{-3}$ & & & & $\mathrm{pH}-\mathrm{S}$ & \\
\hline \multicolumn{16}{|l|}{ Sta. 10} \\
\hline Depth (m) & SSW & SW - & TW & IW & SSW & SW & TW & IW & SSW & SW & TW & IW & SSW & SW TW & IW \\
\hline 50 & 13 & 71 & 15 & 1 & 11 & 67 & 13 & 9 & 6 & 76 & 17 & 11 & 6 & $\begin{array}{ll}71 & 14\end{array}$ & 9 \\
\hline 75 & 7 & 44 & 38 & 11 & 6 & 46 & 35 & 13 & 5 & 50 & 33 & 12 & 6 & $\begin{array}{ll}58 & 28\end{array}$ & 8 \\
\hline 100 & 2 & 18 & 66 & 14 & 3 & 15 & 61 & 21 & 2 & 13 & 66 & 19 & 2 & 1671 & 11 \\
\hline 150 & 0 & 0 & 55 & 45 & 0 & 0 & 61 & 39 & 0 & 0 & 56 & 44 & 0 & $0 \quad 52$ & 38 \\
\hline 200 & 0 & 0 & 41 & 59 & 0 & 0 & 43 & 57 & 0 & 0 & 49 & 51 & 0 & $0 \quad 41$ & 59 \\
\hline 400 & 0 & 0 & 7 & 93 & 0 & 0 & 9 & 91 & 0 & 0 & 8 & 92 & 0 & $0 \quad 9$ & 91 \\
\hline
\end{tabular}

Sta. 12

$\begin{array}{lrrrrrrrrrrrrrrrr}\text { Depth(m) } & & & & & & & & & & & & & & & & \\ 50 & 0 & 82 & 18 & 0 & 0 & 80 & 20 & 0 & 0 & 84 & 16 & 0 & 0 & 85 & 15 & 0 \\ 75 & 6 & 50 & 34 & 10 & 9 & 43 & 41 & 7 & 0 & 76 & 24 & 0 & 0 & 75 & 25 & 0 \\ 100 & 0 & 20 & 66 & 14 & 1 & 15 & 71 & 13 & 0 & 22 & 73 & 5 & 0 & 22 & 70 & 8 \\ 200 & 0 & 0 & 54 & 46 & 0 & 0 & 56 & 44 & 0 & 0 & 52 & 38 & 0 & 0 & 57 & 43 \\ 400 & 0 & 0 & 5 & 95 & 0 & 0 & 8 & 92 & 0 & 0 & 12 & 88 & 0 & 0 & 10 & 90\end{array}$

Sta. 13

\begin{tabular}{lrrrrrrrrrrrrrrrr} 
Depth (m) & & & & & & & & & & & & & & & & \\
50 & 0 & 78 & 22 & 0 & 0 & 80 & 20 & 0 & 0 & 85 & 15 & 0 & 0 & 84 & 16 & 0 \\
75 & 0 & 48 & 52 & 0 & 0 & 42 & 58 & 0 & 0 & 48 & 52 & 0 & 0 & 50 & 50 & 0 \\
100 & 0 & 0 & 100 & 0 & 0 & 0 & 100 & 0 & 0 & 8 & 92 & 0 & 0 & 13 & 87 & 0 \\
200 & 0 & 0 & 58 & 42 & 0 & 0 & 65 & 35 & 0 & 0 & 69 & 31 & 0 & 0 & 79 & 21 \\
400 & 0 & 0 & 10 & 90 & 0 & 0 & 6 & 94 & 0 & 0 & 11 & 89 & 0 & 0 & 12 & 88 \\
\hline
\end{tabular}

get to the surface but shows its influence at the shelf break and near the bottom on the shelf, making up as much as $50 \%$ on the bottom in September, lower in December.

Figure 14(a) and (b) show the mixing ratio of the Kuroshio Intermediate Water in September and December, respectively. The Intermediate Water contributes to the upwelled water at the shelf break and makes up $30 \%$ of the bottom water on the shelf in September, less in December.

Overall, the largest September-December contrast occurs on the shelf. The original "Shelf Water" component makes up 70-80\% of the surface shelf water in September, only $20 \%$ in December. The bottom shelf waters contain only $10 \%$ of the original "Shelf Water" in September and little or no original "Shelf Water" in December. They are composed of $10 \%$ Kuroshio Surface Water, 50\% Kuroshio Tropical Water and 30\% Kuroshio Intermediate Water in September, 30-50\% Kuroshio Surface Water, 30\% Kuroshio Tropical Water and 10-30\% Kuroshio Intermediate Water in December.

There are regions on Fig. 10, say a point $P^{\prime}$ at Sta. 6 where perpendicular lines can not be drawn to all four sides. Such points are near one of the four sides thus are mainly a mixture of two water masses. For instance, point $P^{\prime}$ is mainly a mixture of SW and SSW. The contribution of IW diminishes from the point $P$ to $P^{\prime}$ until IW becomes zero. After that, $P^{\prime}$ can simply be calculated as a mixture of SSW, SW and TW.

\section{CONCLUSION}

We have calculated the mixing ratios of Shelf Water, Kuroshio Surface Water, Kuroshio Tropical Water and Kuroshio Intermediate Water in an area northeast of Taiwan. In 
(a)

station

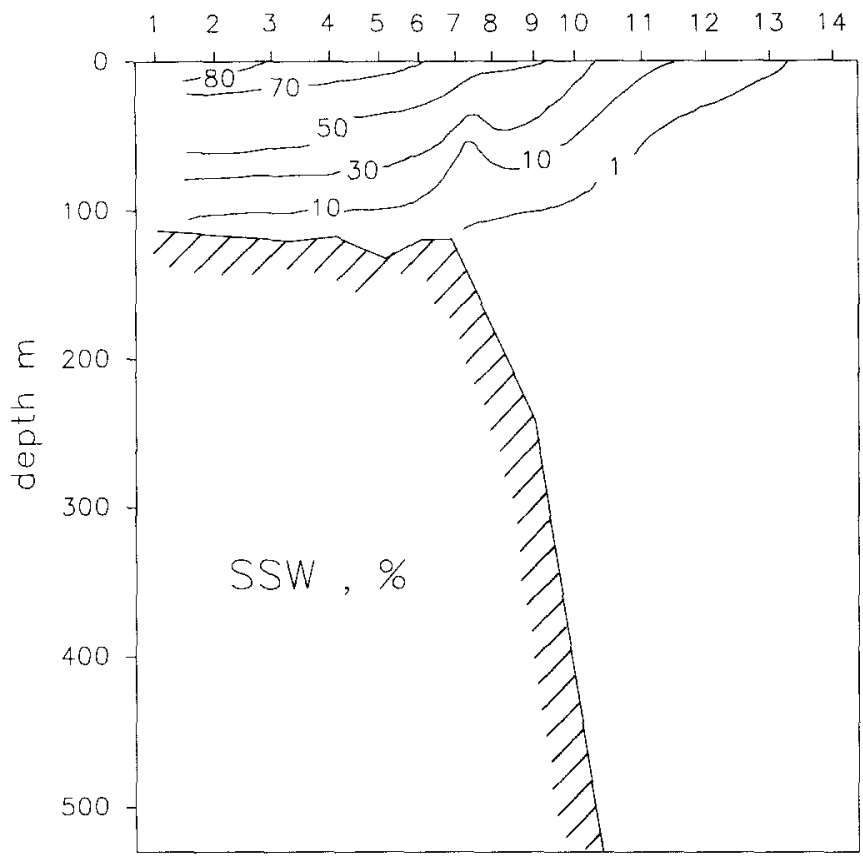

(b)

station

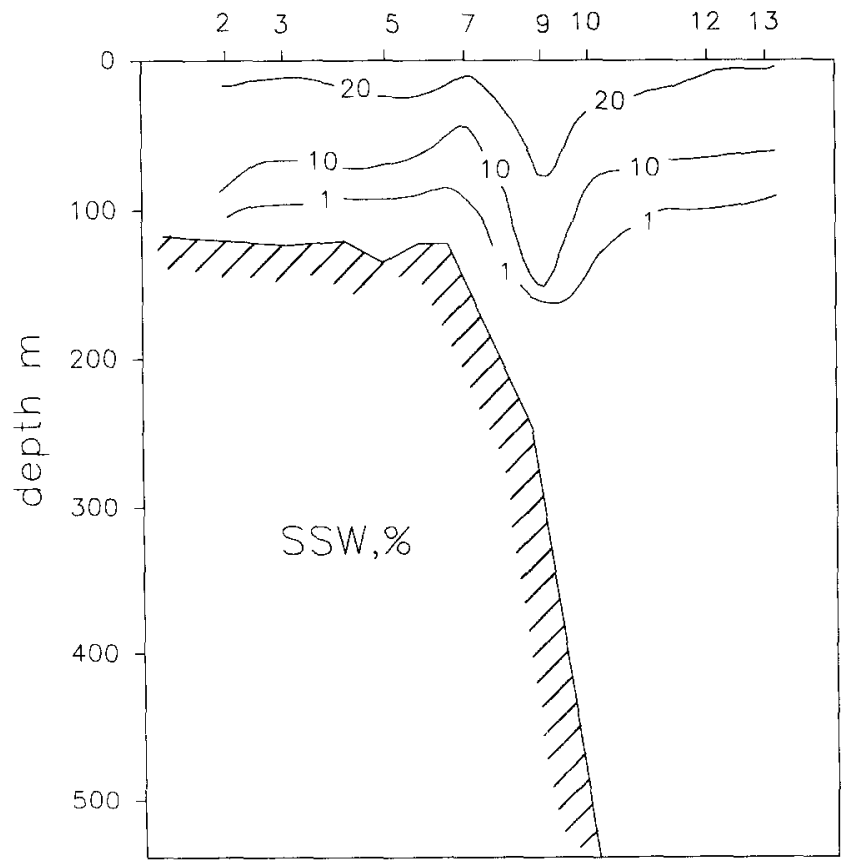

Fig. 11. Cross-section of SSW percentage in (a) September 1988 and in (b) December 1989. 
(a)

station

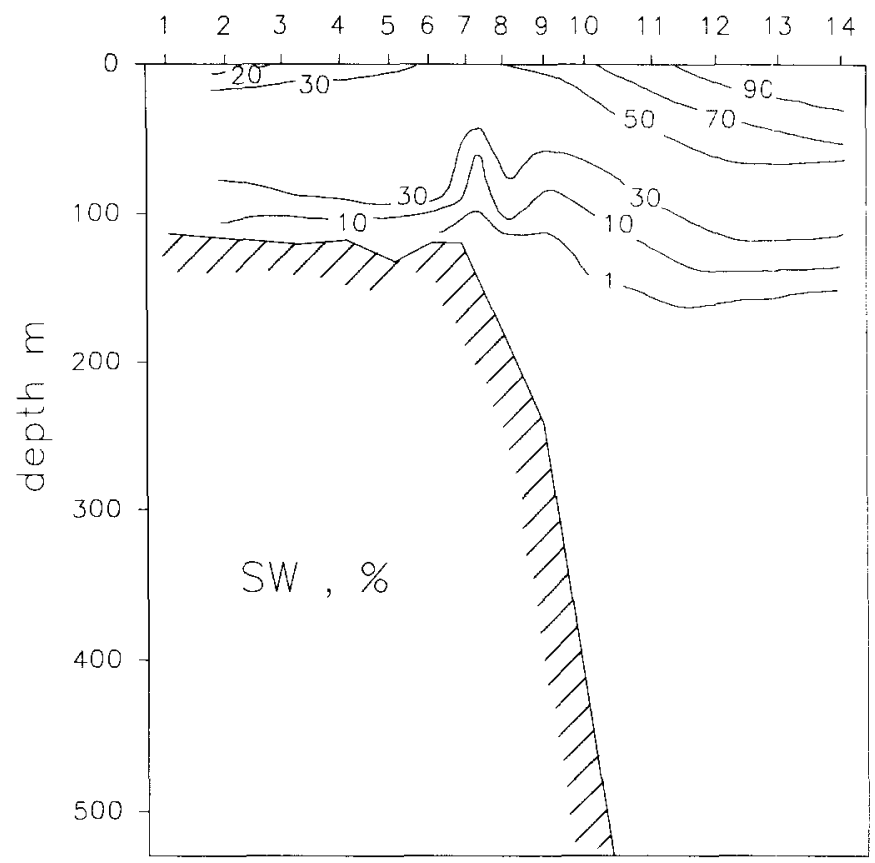

(b)

station

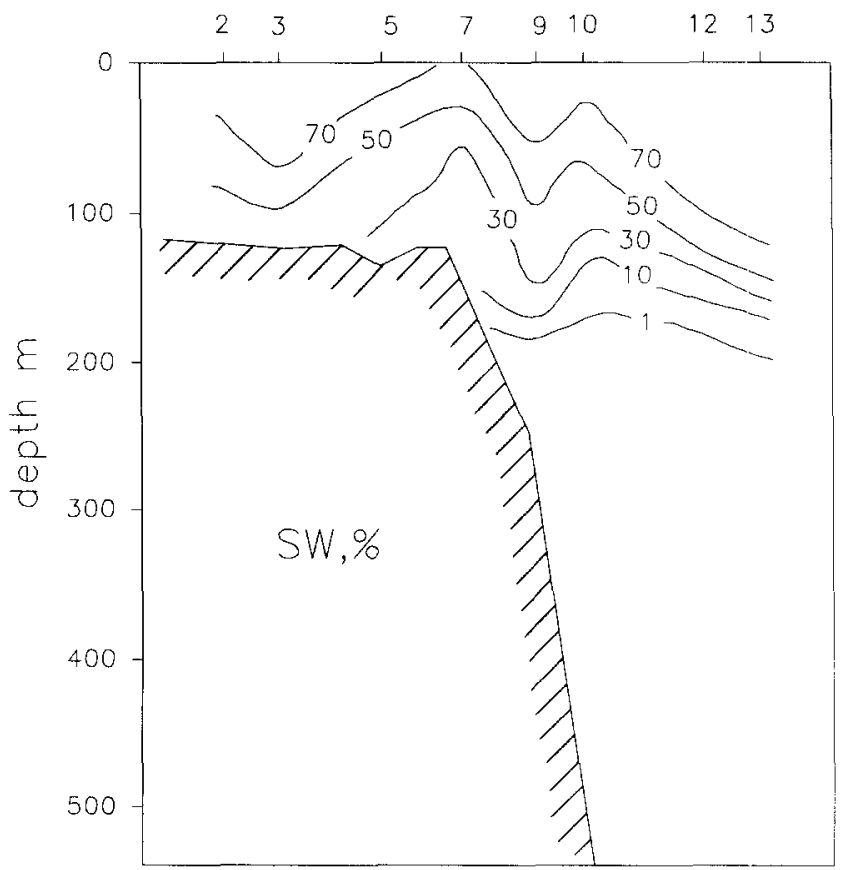

Fig. 12. Cross-section of SW percentage in (a) September 1988 and in (b) December 1989. 
(a)

station

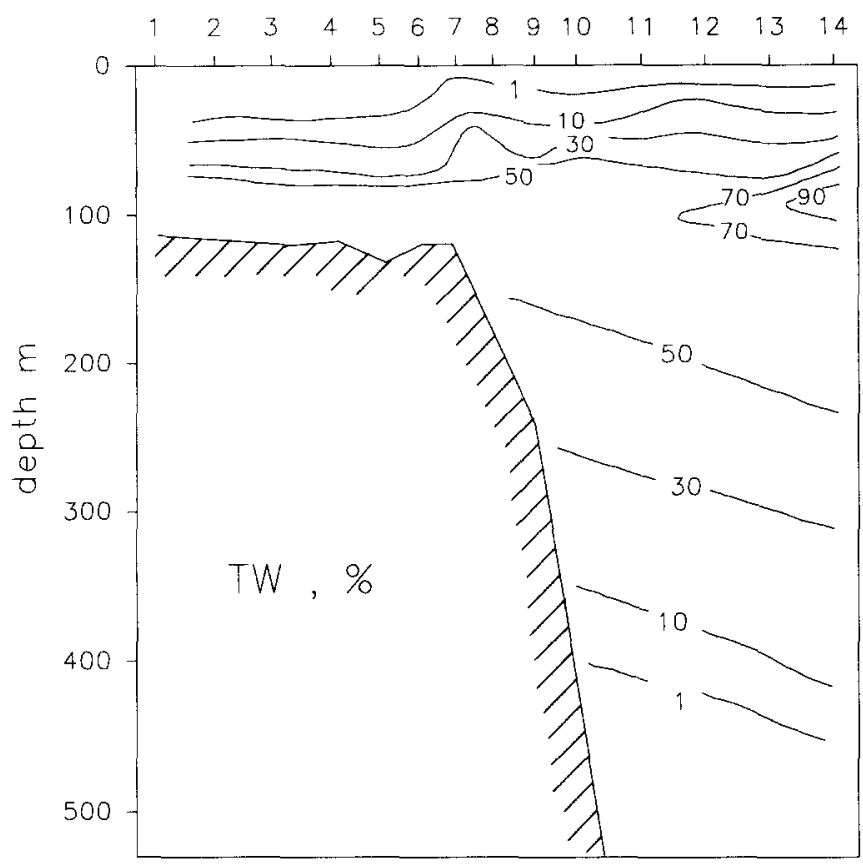

(b)

station

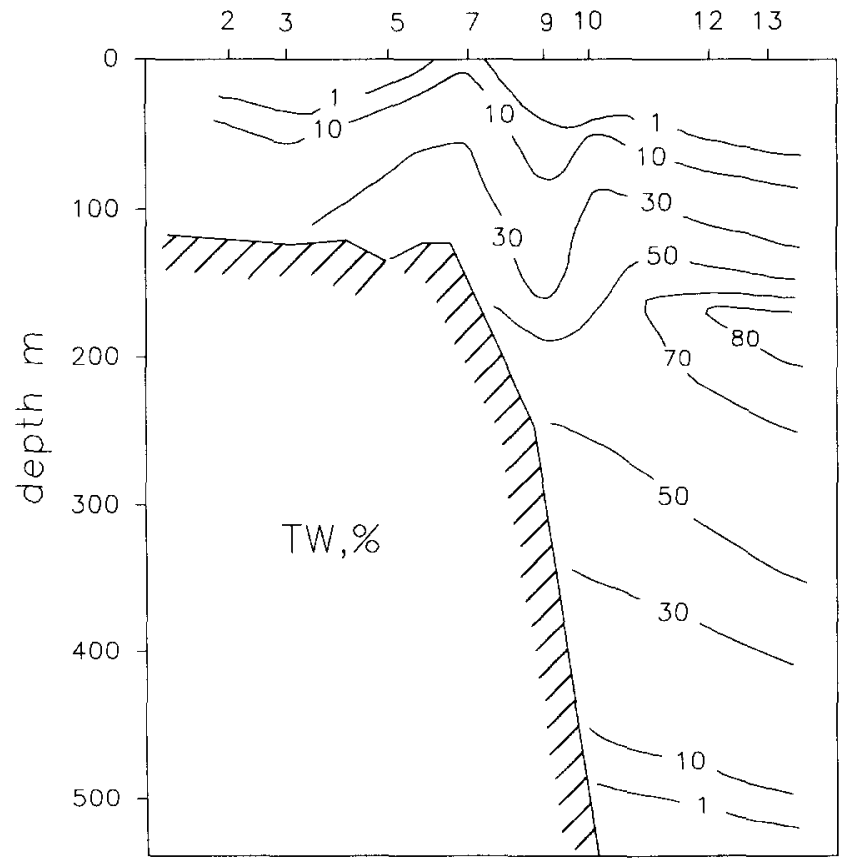

Fig. 13. Cross-section of TW percentage in (a) September 1988 and in (b) December 1989. 
(a) station

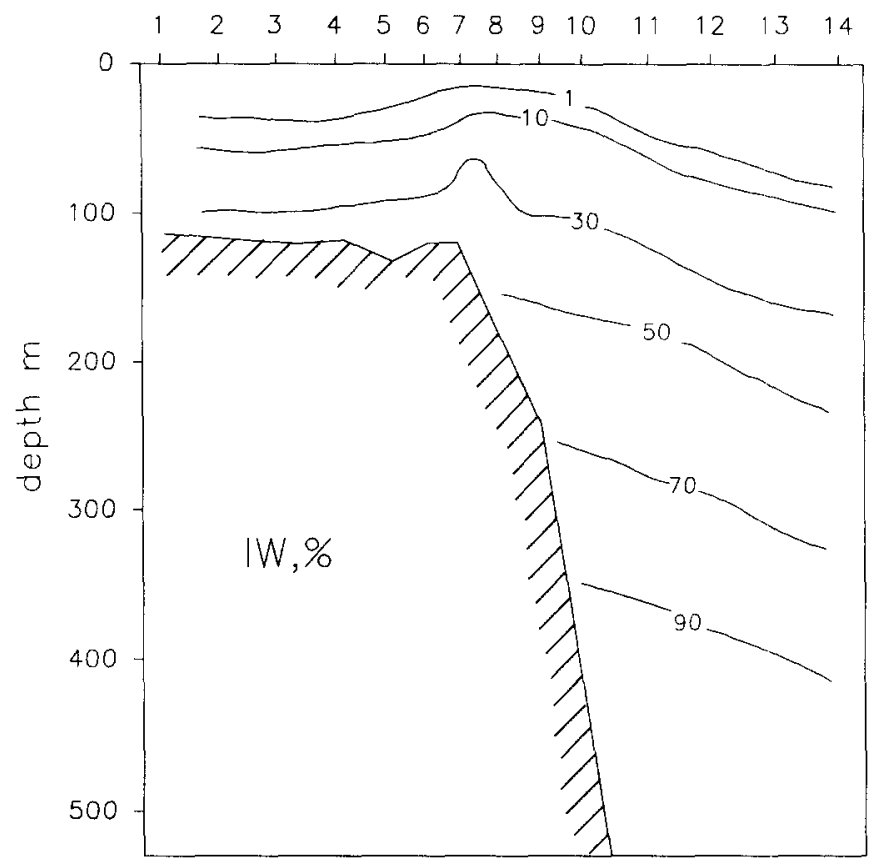

(b)

station

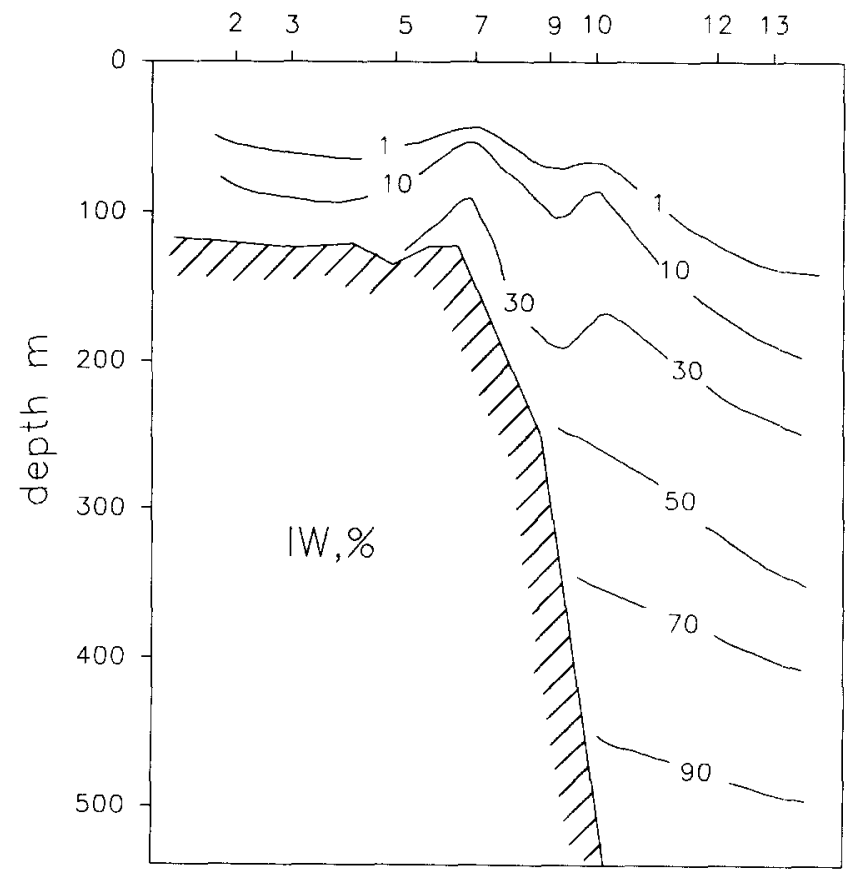

Fig. 14. Cross-section of IW percentage in (a) September 1988 and in (b) December 1989. 
September 1988, surface shelf water in the study area was affected by the Kuroshio Surface Water. The bottom waters on the shelf contained only $10 \%$ of the original "Shelf Water". The rest came from the Kuroshio Surface Water (10\%), Kuroshio Tropical Water (50\%) and the Kuroshio Intermediate Water (30\%).

In December 1989 , the original "Shelf Water" constituted only $20 \%$ of the surface water on the shelf. Intrusion of the Kuroshio Surface Water dominated ( $>70 \%)$. The original "Shelf Water" was almost nonexistent near bottom where Kuroshio Surface Water (30$50 \%)$, Kuroshio Tropical Water (30\%) and Kuroshio Intermediate Water (10-30\%) dominated. The mixing ratios offshore are also calculated and they do not show large temporal variations.

Although it is not apparent on Figs 2-8, Kuroshio Intermediate Water also participated in the upwelling and cross shelf mixing by a higher percentage [ $>30 \%$ near bottom; Fig. $12(\mathrm{a})$ ] in summer than in winter [less than $10 \%$; Fig. 12(b)].

Acknowledgements-This work was supported by the National Science Council of the Republic of China (NSC 82-0209-M110-041). We thank the captains and crew of the R.V. Ocean Researcher I for their assistance during the cruises. Two anonymous reviewers provided constructive criticisms.

\section{REFERENCES}

AtKinson L. P. (1985) Hydrography and nutrients of the southeastern U.S. continental shelf. In: Oceanography of the southeastern U.S. continental shelf, L. P. AtKinson, D. W. MENZEL and K. A. Bush, editors, American Geophysical Union, Washington, D.C., pp. 77-92.

Blanton J. O., L. P. Atkinson, L. J. Pietrafesa and T. N. Lee (1981) The intrusion of Gulf Stream Water across the continental shelf due to topographically-induced upwelling. Deep-Sea Research, 28, 393-405.

Bradshow A. L., P. G. Brewer, D. K. Shafer and R. T. Williams (1981) Measurements of total carbon dioxide and alkalinity by potentiometric titration in the GEOSECS program. Earth and Planetary Science Letters, 55, 99-115.

CARPEnTER J. M. (1965) The Chesapeake Bay Institute technique for the Winkler dissolved oxygen method. Limnology and Oceanography, 10, 141-143.

Chen C. T. (1981) Oxygen solubility in seawater, In: Solubility data series V7. Oxygen and ozone, R. Batrino, editor, Pergamon Press, Oxford, pp. 41-55.

CHEN C. T (1984) Carbonate chemistry of the Weddell Sea. Department of Energy Technical Report, DOE/EV/ $10611-4,118 \mathrm{pp}$.

CHEN C. T. (1985) Preliminary observations of oxygen and carbon dioxide of the wintertime Bering Sea marginal ice zone. Continental Shelf Research, 4, 465-483.

CHEN C. T. A. (1988a) Exchange of water masses between the East China Sea and the Black Stream: a proposed descriptive chemical oceanographic study. Extended Abstract of the Workshop on Kuroshio Edge Exchange Processes, Stony Brook, N.Y., May 4-6 1988, pp. 6.1-6.6

CHEN C. T. (1988b) Summer-winter comparisons of oxygen, nutrients and carbonates in the polar seas. La Mer, 26, $1-10$.

Chen C. T. (1993) Carbonate chemistry of the wintertime Bering Sea marginal ice zone. Continental Shelf Research, 13, 67-87.

Chen C. T. and F. J. Millero (1977) Precise equation of state for seawater covering only the oceanic ranges of salinity, temperature and pressure. Deep-Sea Research, 24, 365-369.

Chen C. T., C. L. Wei and M. R. Rodman (1985) Carbonate chemistry of the Bering Sea. Department of Energy Technical Report, DOE/EV/10611-5, 79 pp.

Chen C. T. A., R. Ruo and Y. C. Chung (1990) Marine chemistry and sedimentation rate in the Philippine Sea. Proceedings, Atomic Energy Council Conference, Dec. 1990, pp. 1-21. [in Chinese].

Chen C. T., L. Luo and M. S. HuAng (1991) Preliminary report of Ocean Researcher 1 cruise 237: December 1618, 1989, off Northeastern Taiwan. Technical Report 11, Institute of Marine Geology, National Sun YatSen University, $72 \mathrm{pp}$. [in Chinese].

CHU T. Y. (1963) The oceanography of the surrounding waters of Taiwan. Institute of Fisheries Biology Technical Report, 1(4), 29-44. 
CSK (1966) Oceanographic data report of CSK, No. 1. Chinese National Committee on Oceanic Research, Academia Sinica, ROC, $123 \mathrm{pp}$.

CSK (1968) Oceanographic data report of CSK, No. 2. Chinese National Committee on Oceanic Research, Academia Sinica, ROC, 124 pp.

CSK (1969) Oceanographic data report of CSK, No. 3. Chinese National Committee on Oceanic Research, Academia Sinica, ROC, 119 pp.

CSK (1970) Oceanographic data report of CSK, No. 4. Chinese National Committee on Oceanic Research, Academia Sinica, ROC, $111 \mathrm{pp}$.

FanNing K. A. and M. E. Q. PILSON (1973) On the spectrophotometric determination of dissolved silica in natural waters. Analytical Chemistry, 45, 136-141.

Huang S. G., J. D. YANG, W. D. JI, X. L. YANG and G. X. Chen (1983) Silicon, nitrogen and phosphorus in the Changjiang river mouth water. In: Proceedings of "Symposium on sedimentation on the Continental Shelf with special reference to the East China Sea", April 1983, Hangzhou, China, Springer-Verlag, pp. 220-228.

LI K. and Z. F. Lu (1987) A preliminary analysis of water masses in the East China Sea in summer and winter. Collected Papers of Kuroshio Research, Ocean Press, Beijiang, pp. 177-189 [in Chinese with English Abstract].

LimeburNer R., R. C. Beardsley and J. S. Zhao (1983) Water masses and circulation in the East China Sea. In: Proceedings of "Symposium on sedimentation on the Continental Shelf with Special Reference to the East China Sea", April, 1983, Hangzhou, China, Springer-Verlag, pp. 261-269.

Liu K. K., G. C. Gong, C. Z. Shyu, S. C. PAI, C. L. Wer and S. Y. Chao (1992) Response of Kuroshio upwelling to the onset of the northeast monsoon in the sea north of Taiwan: Observations and a numerical simulation. Journal of Geophysical Research, 97, 12,511-12,526.

MAo H. L., Y. W. ReN and K. M. WAN (1964) A preliminary investigation on the application of using $T-S$ diagrams for the quantitative analysis of the watermasses in the shallow water area, Oceanologia et Limnologia Sinica, 6, 1-22 [in Chinese with English Abstract].

Miller A. R. (1950) A study of mixing processes over the edge of the continental shelf. Journal of Marine Research, 9(2), 145-160.

Murphy J. and J. P. Riley (1962) A modified single solution method for the determination of phosphate in natural waters. Analytica Chemica Acta, 27, 31-36.

Nitani H. (1972) Beginning of the Kuroshio. In: Kuroshio, H. Stommel and K. YoshidA, editors, University of Washington Press, Seattle, pp. 129-163.

Ruo R. (1989) Preliminary descriptive chemical Oceanography off northeast Taiwan. M.S. thesis, Institute of Marine Geology, National Sun Yat-Sen University, 87 pp. [in Chinese with English Abstract].

Rou R. and C. T. CheN (1991) Descriptive chemical oceanography off northeast Taiwan: the comparisons between summer and winter. Bulletin of Marine Science and Technology, 9, 1-23 [in Chinese with English Abstract].

Strickland J. D. H. and T. R. Parsons (1972) A practical handbook of seawater analysis. Fisheries Research Board of Canada, Ottawa, Canada, $310 \mathrm{pp}$.

Sur Y. N. (1986) Seawater total alkalinity and its qualitative characteristics. Journal of Shandong College of Oceanography, pp. 160-172 [in Chinese].

UDA M. (1941) The results of the hydrographical surveys in the China Sea in summer 1939. Journal of the Imperial Fishery Experimental Station, 11, 39-97 [in Japanese with English Abstract].

WANG S. L. (1988) Dissolved carbonate chemistry in waters surrounding Taiwan. M.Sc. thesis, Institute of Marine Geology, National Sun Yat-Sen University, 102 pp. [in Chinese with English Abstract].

WENG X. C. and C. M. WANG (1985) A study on Taiwan Warm Current Water. Marine Sciences, 9, 1-10 [in Chinese with English Abstract].

Wong G. T. F., S. C. Pal, C. T. A. Chen, T. H. FAng, Y. T. Yeh, G. C. Gong, C. C. YAng, C. C. Hung, C. W. CHEN, J. S. LIN and L. Luo (1989a) Hydrography and chemistry at the frontal region of the Kuroshio-East China Sea. Preliminary report of the Ocean Researcher 1 cruises KECS 1-3, Institute of Oceanography, National Taiwan University Special Report, 59, $131 \mathrm{pp}$.

Wong G. F. T., S. C. PAi and C. T. A. Chen (1989b) Chemical hydrography across the East China Sea-Kuroshio frontal region north-east of Taiwan, Acta Oceanographia Taiwan, 23, 1-18.

Wong T. F., S. C. PAI, K. K. LiU, C. T. Liu and C. T. A. ChEN (1991) variability of the chemical hydrography at the Frontal Region between the East China Sea and the Kuroshio north-east of Taiwan. Estuarine and Coastal Shelf Science, 33, 105-120.

YANG T. H. (1984) A preliminary investigation of the Kuroshio watermass in the East China Sea. Studia Marina Sinica, 21, 179-199 [in Chinese with English Abstract]. 